\title{
A Brief History of the Internet in Saudi Arabia
}

\author{
Hamed A. Alshahrani ${ }^{1}$
}

Published online: 15 January 2016

(C) The Author(s) 2016. This article is published with open access at Springerlink.com

While the Internet has developed into a pivotal tool in world communications, Saudi Arabia was quite late in connecting it to the public, compared with developed or even other developing countries (Al-Hajery 2004). The delay in launching the Internet in Saudi Arabia came from the government's concerns and reservations about the effects of such a new service on their conservative culture. In Saudi Arabia, academic institutions were the first sectors to use the Internet before it was available to the public.

According to Al-Tawil (2001). "King Fahd University of Petroleum and Minerals (KFUPM) in Dhahran was the first institution to connect to the Internet in 1993 through the College of Computer Sciences and Engineering" (p.2). However, due to the low speed of the connection, only email was provided to KFUPM. Later, King Abdulaziz City for Science and Technology (KACST), an independent scientific organization administratively reporting to the Prime Minister of Saudi Arabia, provided internet service to KFUPM using a $64 \mathrm{kbps}$ channel from the King Faisal Specialist Hospital and Research Center (KSHRC). In 1995, KACST made the first effort to connect more Saudi universities to the Internet through the KSHRC, which was, itself, connected to the Internet through its own satellite station (Al-Hajery 2004).

On March 1997, the Council of Ministers officially issued Decree Number 163. This gave the responsibility of introducing Internet service, in terms of organization and operation within Saudi Arabia, to KACST. Qualifications for Internet Service Providers (ISPs) were announced by KACST in

Hamed A. Alshahrani

halshahrani@niu.edu

1 Northern Illinois University, DeKalb, USA
December 1998, and KACST cooperatively worked with the Saudi Telecommunications Company (STC) to provide the necessary communication lines (Al-Hajery 2004). STC "provides, manages and maintains the telecommunication infrastructure in the country. It provides the linkage between customers and ISPs, between ISPs and the KACST network, and between KACST and the international network" (MOCIT, 2003, p.8).

KACST established an Internet Service Unit (ISU) with responsibility of making the service available to the public, while, at the same time, protecting the values and Islamic beliefs of the Saudi society (Al-Tawil 2001). KACST is directly responsible for filtering information provided by different sites on the Internet before passing them to users within the country. KACST also "manages and operates the international lines through which the national Internet network is connected to the international network; it supervises the Internet gateway and blocks undesirable sites" (MOCIT, 2003, p.8).

The service provider acted as a Saudi exchange point, worked to raise public awareness of the Internet, formulated rules and regulations to govern the use of the Internet in the Saudi Arabian community, and operated the Saudi domain name system.

Early on, STC was the only Internet service provider in Saudi Arabia. But in May 2005, Mobily, a new telecommunications company, launched the Saudi Arabian mobile market. Three years later, August 2008, Zain joined the Saudi Arabian mobile market as another ISP, introducing 4G LTE (Long Term Evolution) services. Also in 2008, Saudi Telecom started the $3 \mathrm{G}$ deployment process, promising reliability and speed, as well as better digital communication services (Chanchary and Islam 2011).

Although, the Internet was only made available in 1999, Saudi Arabia has grown greatly in this area, especially in 
terms of connectivity. There has been a notable increase in the number of Internet users in Saudi Arabia. For instance, the total number of Internet subscribers in Saudi Arabia increased dramatically from 100000 internet users in 1999 to one million internet users in 2001. At the end of 2013, that number reached 16.5 million Internet users, representing $55.1 \%$ of the country's total population (CITC, 2014; MOCIT, 2003). Alebaikan and Troudi (2010) stated that "it is estimated that Internet use will continue growing rapidly in Saudi Arabia, which raises an issue of providing new learning strategies that include use of technology" (p.51). Almost all universities, colleges and other educational institutions in Saudi Arabia have free Internet access. Faculty, for example, use email and develop classroom home pages that provide information about classes, including the syllabus, general instructions, exercises, assignments, examples, useful links, and literature references to facilitate the teaching process. The Internet also motivates students to get immediate access to information, find convenient references, and study independently. Lastly, numerous hospitals in Saudi Arabia as well as banks and corporations are offering more of their services online.

Consequently, the Internet penetration increased dramatically from one million Internet users in Saudi Arabia in 2001 to approximately 16.5 million Internet users at the end of 2013, representing $55.1 \%$ of the country's total population (CITC, 2014).
Alshahrani A. Hamed is a doctoral student in the Department of Educational Technology, Research and Assessment at Northern Illinois University, DeKalb, IL. Please direct correspondence regarding this column entry to him via email to: halshahrani@niu.edu.

Open Access This article is distributed under the terms of the Creative Commons Attribution 4.0 International License (http://creativecommons. org/licenses/by/4.0/), which permits unrestricted use, distribution, and reproduction in any medium, provided you give appropriate credit to the original author(s) and the source, provide a link to the Creative Commons license, and indicate if changes were made.

\section{References}

Alebaikan, R., \& Troudi, S. (2010). Blended learning in Saudi Universities: challenges and perspectives. ALT-J: Research in Learning Technology, 18(1), 49-59.

Al-Hajery, E. (2004). History of the Internet in the Kingdom of Saudi Arabia (In the Arabic). Riyadh: Al Obeikan.

Al-Tawil, K. (2001). The Internet in Saudi Arabia. Telecommunications Policy, 25(8), 625-634. doi:10.1016/S0308-5961(01)00036-2.

Chanchary, F. H., \& Islam, S. (2011). Paper presented at the international Arab conference on information technology (ACIT'2011). Jordan: Zarqa University. Mobile learning in Saudi Arabia - prospects and challenges.

Communications and Information Technology Commission (CITC) (2014). Annual report 2014. Retrieved from http://www.citc.gov. sa/english/Pages/default.aspx

Ministry of Communications and Information Technology (MOCIT) (2003). Information and telecommunication technology in Saudi Arabia (Report No. WSIS/PC- 3/CONTR/25-E), World Summit on the information society, Geneva. 